\title{
The Incorporation of Jesus and his Emissaries in a Tripartite Canonical Framework (Luke 11:45-53)
}

\author{
Gregory S. Thellman \\ Visoko evanđeosko teološko učilište, Osijek \\ greg.thellman@evtos.hr
}

UDK: 27-246

Original scientific paper

Received: March, 2017

Accepted: April, 2017

\begin{abstract}
This composition critical exegetical study examines Luke's distinctive presentation of Jesus' woes against the scribal scholars in Luke 11:45-51. Four elements of Luke's presentation are identified which contribute to the inclusion of Jesus and his emissaries within a distinctly tripartite canonical framework. Luke's peculiar use of the Greek term vouixós is shown to be employed as a rhetorical marker to emphasize the scripture interpreting role of the scribal scholars and to provide a broad allusion to scripture overall. The correspondence of the three woes against the voulxoi to the tripartite Hebrew canon is demonstrated as further evidence for this allusion to scripture and a threefold revelatory tradition. Two elements within the second woe, the saying of the "Wisdom of God," and the range of past martyrs, are then discussed and found to have intertextual links with 2 Chronicles 24 and 36, suggesting the present passage is a typological recapitulation of past persecution and martyrdom, as well as judgment. The article concludes that these distinctive elements show that Luke typologically incorporates Jesus and his emissaries within a tripartite revelatory tradition and canonical framework, and that by further implication, Luke's written testimony (Luke-Acts) to the persecution and killing of Jesus and his sent ones, contributes to the self presentation of this written testimony as a climactic continuation of the OT scriptures.
\end{abstract}




\section{Introduction}

One of the major characteristics of the reformers' view of scripture is that of its self-authenticating or self-attesting nature (Kruger, 2012, 89). Congruent with that understanding is a growing perception that the authors of New Testament books, particularly the Gospels, may have indeed presented their works as authoritative scripture in climactic continuity with the OT scriptures they knew so well (Smith, 2000; Balla, 2002, 373-75; Kruger, 2013, 119-54). The very content of the written Gospels in particular- the eschatological fulfillment of the OT scriptures and messianic authority of Jesus-imparts an inherent authoritative claim for these writings (Balla, 2002, 375). But in addition, certain narrative and theological tendencies of the Gospels also point to their self presentation as scripture (Smith, 2000). ${ }^{1}$

The present work contributes to this view by arguing that Luke's peculiar presentation of Jesus' rebuke of the scribal scholars in Luke 11:45-54 incorporates Jesus and the "apostles and prophets" sent by him among the canonical prophets, and within a tripartite canonical framework. By implication, this argument supports the notion that Luke's written testimony of the ministries and persecutions of both Jesus and his sent ones in his two volumes (Luke-Acts) inherently presents itself as a continuation of that canonical framework-the OT scriptures. As a composition critical study, this work will make limited use of certain details of the Matthean parallels (ch. 23) and the underlying source or tradition commonly referred to as Q. However, the focus of this essay is not on Q or the common tradition, but rather on Luke's implementation of his source materials for his overall narrative and theological purposes.

Four elements of the passage contribute to make the case for this allusion. First, Luke's unusual choice of vouixós for 'scribe' in this passage serves rhetorically to emphasize the scribal role of Torah or scripture interpretation and teaching. Second, the three woes delivered to these scribal scholars thematically corresponds to an existing canonical framework, the three revelatory streams represented in the traditional Hebrew canon-law, prophets and wisdom (or writings) - suggesting an allusion to scriptural history and revelation.

Third, the revelatory authority of the speech of the "Wisdom of God" cited by Jesus (Luke 11:49; Matt 23:34) signals a climactic recapitulation of revelatory history in the ministry and persecution of Jesus and his apostles. Fourth, Luke 11:51 establishes a canonical range of martyrs from Abel to Zechariah with the implication that the coming martyrs of the Jesus movement typologically recapitulate scriptural history, though in a climactic fashion. 


\section{Luke's Employment of vouixós for "Scribe”}

Luke 11:45-54 is only the second half of a larger pericope (11:37-54) that narrates Jesus' attendance at a meal hosted by a Pharisee, and attended by other Pharisees and another group referred to in Greek as vouixoi. After the first half, where Jesus pronounces three woes against the Pharisees (11:37-44), Luke shifts the narrative to focus on the voulxol, a second group of opponents, sometimes translated "lawyers," or "experts in the law", or even merely "scribes" (Bock, 1996, 1118). Although all six of the woes may be found to have parallels in Matthew, the meal setting, the distinction between the two groups and the use of voulxós to refer to the scribal group-related to but somehow distinct from the Pharisees-are all Lukan peculiarities. For the sake of consistency, from this point on I will refer to this group as "scribal scholars" for reasons that will become clearer throughout the article.

The separate introduction of the scribal scholars (11:45) is rather unlike the synoptic parallels throughout Matthew 23 where Jesus pronounces the woes against scribes and Pharisees together. However, the Matthean term translated "scribe" in these passages, like in Mark and in most of Luke's usage, is the

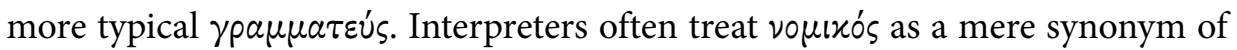

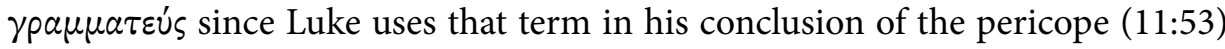
to apparently refer to the same group (Marshall, 1978, 499; Nolland, 1993, 2:666; Bock, 1996, 2:1118). ${ }^{2}$ However, few offer any explanation as to why Luke uses vонıко́ here $(11: 45,46,52)$, especially when he returns to describe the same

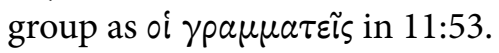

BDAG (675) defines vouıxós primarily as an adjective referring to something related to the law, and secondly as referring to a person "learned in the law." The majority of occurrences in the second category pertain to lawyers and jurists in Greco-Roman society. It is a fairly common word in Greek literature, but rarely used to refer to the law in the Jewish sense, that is, to the Torah. There are only five instances of this word in specifically Jewish Greek literature through the first century outside of the canonical Gospels. ${ }^{3}$ Of these, three are clearly used as attributive adjectives and one (Titus 3:13) refers to a lawyer but most likely in the Greco-Roman sense. None of these instances imply a special class of Jewish leaders.

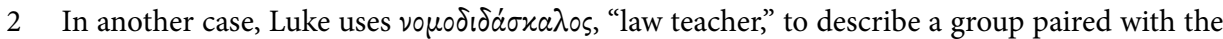
Pharisees (5:17; cf. Acts 5:34 where the same word is used to describe Gamaliel), but this group is also called "scribes" ( the term is found in 1 Tim 1:7.

3 Titus 3:9, 13; Philo, On the Special Laws, IV.64; Sibylline Oracles, 8.112; and 4 Macc 5:4, which will be examined in detail below. 
However, 4 Maccabees 5:4 is an intriguing example that may shed light on Luke's usage. Set in the diaspora of the first century A. D., ${ }^{4}$ the book clearly has a Hellenistic background (deSilva, 1998, 11). However, Paul Redditt (1993) persuasively argues that the faithful living out of the Jewish law (vónos) undergirds the author's concerns for his readers.

The book is named after the Maccabees because the author uses the martyrdom of Eleazar and the mother with her seven sons recorded in 2 Maccabees $(6: 18-7: 42)$ as illustrations for his main point. What is most interesting for the present inquiry is the portrayal of the character of Eleazar by the author of $4 \mathrm{Mac}-$

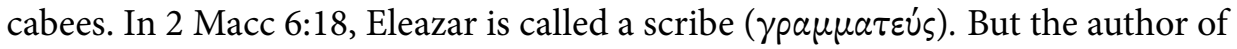
4 Maccabees describes Eleazar as follows:

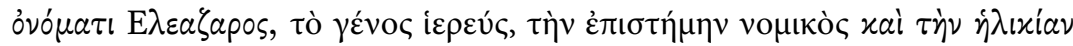
$\pi \rho \eta^{\prime} x \omega \nu$

“... Eleazar by name; with regard to ancestral stock, a priest; with regard to experience, skilled in the law; and with regard to age, advanced ..."

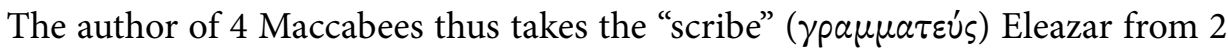
Maccabees and describes him as a priest by ancestry, and "advanced" regarding his age, but regarding his skill or vocation, a vouıxós. ${ }^{6}$

This information from 4 Maccabees is useful in a number of ways. First, as another first century A.D. Jewish-Greek document, it confirms the general syn-

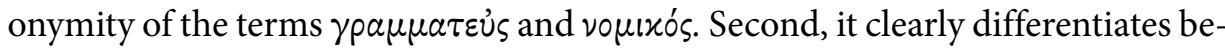
tween ancestral identity and vocational identity, importantly employing vouıxós explicitly as a vocational term, and not that of a distinct party or heredity. ${ }^{7}$ Third, in light of Reddit's understanding (1983), the rhetorical advantage of employing

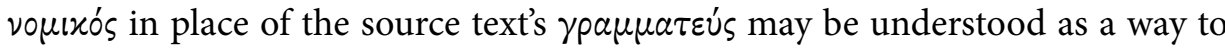
give further emphasis to the faithful living out of the Jewish Torah.

Aside from 4 Maccabees, Luke's explicit use of vouıxós to refer to a group of Jewish scribes is otherwise unique in extant Jewish Greek literature, with the possible exception of Matthew 22:35, which, along with Luke 10:25 appears to

4 There appears to be a consensus on a first century date according to deSilva (2006, xiv), but there is also strong evidence for a more precise dating between 20-54 A.D. (Bickerman, 1945).

5 Translation by deSilva $(2006,15)$. In his commentary section, deSilva simply refers to Eleazar as a "scribe" without any further discussion.

6 His dual identity is further confirmed in 4 Macc 5:35 where both the practice of priesthood and law is repeated.

7 For the common overlap between priestly ancestry and the scribal vocation, see Thellman (2013). 


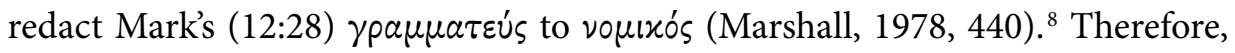
Luke's preference for the term ( 6 appearances) suggests he had a special rhetorical purpose for it.

\section{Scribes and Scribal Scholars in Luke}

In order to ascertain the rhetorical function of vouıxós in Lk 11:45-53, it is helpful to first consider Luke's overall presentation of scribes and scribal scholars, and the progression of Luke's narrative from Jesus' ministry in Galilee (3:239:50), to the travel narrative (9:51-19:27), and finally to Jesus' arrival in Jerusalem (19:28). Luke's presentation of Jesus' opponents is very consistent across these sections. The main opponents before the arrival in Jerusalem are the Pharisees, who make their final appearance in 19:39. According to Saldarini, the Pharisees in Luke, more than in the other synoptic gospels, had "an important social station in Galilee," and saw Jesus as a threat to their position $(1988,178)$. However, as Gowler $(1994,236)$ argues, Luke consistently keeps the Pharisees separated from direct association with Jesus' death. ${ }^{9}$

Upon arrival in Jerusalem, the new main group of opponents are the chief priests, who are consistently associated with Jesus' death. The chief priests only appear in the narrative after Jesus arrives in Jerusalem with the lone exception being Jesus' foretelling of his passion in 9:22. They are thus always associated with Jerusalem, the plot to kill Jesus, and his trial and execution. ${ }^{10}$ Scribes, in contrast to both of these groups, cut across these geographical divisions and are present from Galilee, through the travel narrative, and in Jerusalem as part of the plot against Jesus. However, this is not surprising considering that scribalism was neither a hereditary identification, nor a party, but a vocation, as 4 Macc 5:4 makes clear. As such, terms for "scribes" could cut across hereditary and party lines (Thellman, 2013).

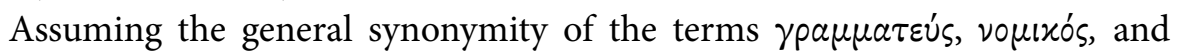

8 However, the precise synoptic relationship here is problematic because there are correspondences between Matthew and Luke that differ from Mark, like the use of voulxós, which appear to point to a non-Markan tradition common to Matthew and Luke (Davies and Allison, 1997, 235-36). Compounding the problem is that the Matthean vouıxós is not present in some manuscripts. It is not possible here to explore these problems in detail, but the textual question does allow for the possibility that the occurrence in Matthew was a later insertion based on the Lukan parallel (Schams, 1998, 172). This scenario would be consistent with each author's usage throughout their writings and would mean that the explicit use of vouıxós to designate Jewish scribes is exclusively a Lukan phenomenon.

9 Similarly, Saldarini $(1988,179)$ describes the Pharisees in Luke as neither friendly nor hostile.

10 The elders are also typically associated with the chief priests, but feature less prominently in Luke than in Matthew and Mark. 


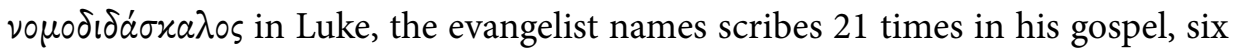

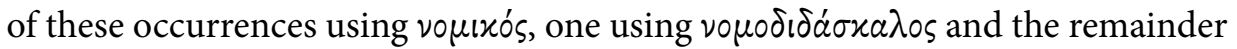

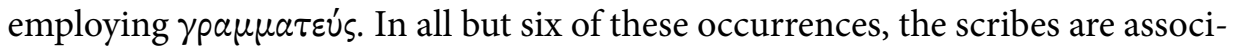
ated with another named group as part of a larger opposition to Jesus. Eight times they are associated with the Pharisees from 5:17 to 15:2, and seven times they are associated with the chief priests-six times from 19:4 to 23:10, and once in 9:22 where Jesus foretells his passion.

Where scribes are explicitly associated with another group, namely the Pharisaic party, or the chief priests of Jerusalem, they appear to take on the role and purpose of that particular group, thus suggesting each group contained a sub-group of scribes who were their representative scholars. ${ }^{11}$ Thus, in episodes where scribes are paired with the Pharisees, the issues at hand have to do with purity $(5: 30 ; 15: 2)$, or concerns about Jesus' healing activity on the Sabbath (6:7; 14:3). In addition, Luke comments about their mutual rejection of John's baptism (7:30), and hostility to Jesus (11:53). ${ }^{12}$ The only other Pharisee-Scribe coalition is described in 5:17-26 where Jesus' authority to forgive sins is questioned. But this passage somewhat defies easy categorization since Luke 5:17 entails the

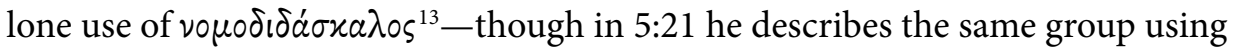

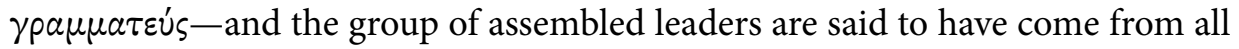
over Galilee as well as Judea and Jerusalem. It seems likely that the law teachers

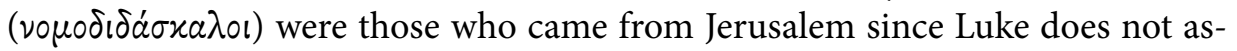
sociate the Pharisees with Jerusalem.

This passage might function as an important bridge between the scribes who are associated with the Pharisees in Galilee and the scribes associated with the chief priests in Jerusalem. The issue of Jesus' authority is prominent in this pericope as well as in 20:1-19 where Jesus is challenged by the chief priests and scribes. All of the other instances of the chief priest-scribe coalition deal with the plotting of Jesus' death and his trial $(19: 47 ; 22: 2 ; 22: 66 ; 23: 10)$. In sum, when the scribes are associated as a group with another prominent group of Jesus' opponents, the Pharisees or chief priests, they basically take on the character of that group. ${ }^{14}$ The issue that may bridge the two sets of scribes is the issue of Jesus'

11 This kind of affiliation is made explicit in Luke 5:30 where Luke refers to the Pharisees and "their scribes."

12 Since this is part of the pericope under consideration, it will be dealt with in more detail below.

13 He uses this word once in Acts (5:34) to describe Gamaliel, who is also a Pharisee and part of the Sanhedrin.

14 This fits with Saldarini's $(1988,273)$ conclusion that the scribes did not form a "unified class or organization." But various groups of scribes might have been associated with various different classes or organizations. 
authority, but this may have been more of an issue in particular for the Jerusalem scribes, who, along with the closely aligned chief priests, saw Jesus' authority as a challenge to their own.

However, in the two passages where the Pharisees are aligned specifically

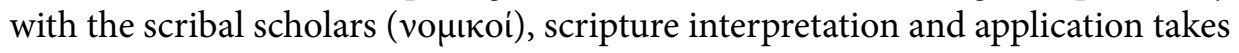
a prominent role $(7: 27-30 ; 14: 1-6)$. In the first instance, the Pharisees and scribal scholars have rejected John's baptism due to their failure to understand John's eschatological identity in light of Mal 3:1, earlier cited by Jesus. In the second case, Jesus challenges the gathering of Pharisees and scribal scholars regarding the legality of healing on the Sabbath by alluding to two Torah texts (Deut 22:4 and Exod 23:5).

Indeed, scripture interpretation is the subject matter in the three instances apart from Luke 11:45-52 where scribes appear without a partner group. One of these is

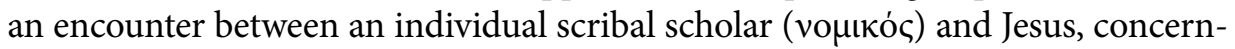
ing the greatest commandment (10:25). The matter at hand is explicitly referred to by Jesus as a question regarding the Jewish Torah (vómoc) and the scribal scholar quotes Deuteronomy when prompted by Jesus to answer his own question.

The next two are instances where scribes (here $\gamma \rho \alpha \mu \mu \alpha \tau \varepsilon \tilde{c} \varsigma$ ) are referred to collectively $(20: 39 ; 20: 46)$. In the former case, the scribes appear to applaud Jesus' use of Exod 3:2-6 to answer the Sadducees' challenge regarding the question of the resurrection. ${ }^{15}$ In the latter, Jesus questions the scribes' interpretation of a cited messianic text (Psalm 110:1) and then levels a harsh criticism against their hypocrisy and arrogance. Thus, in each of the three instances where scribes are referred to without any explicit coalitions with other groups, and in two cases

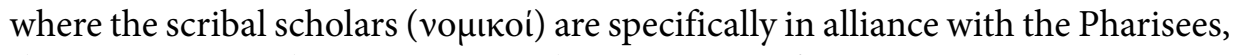
the interaction with Jesus is centered on questions of correct scripture interpretation and its application, and contains explicit scriptural quotations or allusions. ${ }^{16}$ These observations show that for Luke, whatever else may have defined Jewish scribes, scripture knowledge, interpretation and teaching, are among their primary roles (Thellman, 2013). ${ }^{17}$ It also suggests that when scribes are paired with Pharisees in texts where scripture interpretation and application is an important element, Luke prefers the term vouixós.

15 The issue at hand implies that these scribes are at least aligned with the Pharisaic party.

16 For more on this, and on the scribes in the gospels in general, see Thellman (2013).

17 The same could be said for the other synoptic evangelists, as well as Ben Sira (38:24-39:11). Schams $(1998,15-35)$ provides a critical but helpful summary of the history of scholarship on this question since Schürer. Although Schams finds that most scholarship following on the heals of Schürer's notion of the Schriftgelehrte to be faulty, her own conclusion is that scribes were primarily writers, but concedes that "some scribes will have been known as. . expert interpreters of the scriptures and the law" (327). 


\section{The Scribal Scholars (voutкoi) in Luke 11:45-53}

In the above survey of Luke's presentation of scribes and lawyers, all three

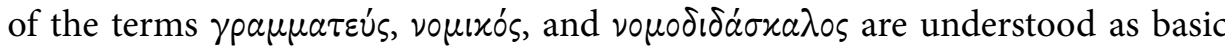
synonyms due to passages where Luke clearly uses both terms to refer to the same group (5:17 and 5:21;11:45-52 and 11:53). However, simply acknowledging the synonymity does not address why Luke may have used this otherwise rarely used term (vouixós) in 11:45-52. ${ }^{18}$

Saldarini suggests that Luke uses vouıxós because "in the author's world lawyers rather than scribes functioned as authoritative experts in social and religious law and customs" (183). While this may be partially true, Saldarini was earlier skeptical of the notion that Luke used the term as an "aid to his Gentile audience" (1988, 183; cf. Schams, 1998, 171). Indeed, if this was Luke's reason, one would expect him to employ only vouixós, in both his redactions and special material,

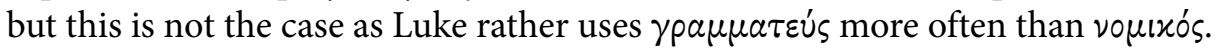

Another possibility is that the meal scene here and elsewhere in Luke follows the literary tradition of the Hellenistic Symposium (Steele, 1984, 379; Smith, $1987,613)$. In that case, the term voulxós may have been a more natural fit and would have better represented the honored guests of higher social status (Steele, 1984, 381). This argument is strengthened by the use of voulxós in Luke 14:3, one of three scenes considered to be examples of the Symposium genre (Steele, 1984, 184). However, this possibility does not explain the use of vopuxós in 7:30 and 10:25, two passages which have no link to a particularly Hellenistic background, but which, as noted above, rather deal with thoroughly Jewish questions and, in particular, scripture interpretation. Moreover, in the other suggested Symposium scene, 7:36-50, Luke does not include scribes at all.

A final possibility is that Luke uses voulxós to emphasize the notion of scribes as Torah interpreters and teachers for the purpose of alluding more emphatically to the three-fold revelatory tradition in the three woes (see below). It has already been shown above that whenever scribes appear alone, the topic at hand always revolves around questions of scripture interpretation and includes scriptural quotations, and that where scribes are paired with Pharisees and scripture interpretation takes center stage, Luke prefers the term vouıxós (7:30). In the present passage, the scribes, or scribal scholars, both appear alone, but are also associated with the Pharisees.

These observations suggest that Luke employs vouixós as a rhetorical device to intensify the association of scribes with Torah interpretation. ${ }^{19}$ The adjectival

18 Most commentators simply call these words synonyms and do not deal with reasons why one or the other is used. 
meaning of "skilled in the law" and the shared root with the noun vó $\mu$ os may have proved for Luke an effective way to draw readers to think more directly about this central aspect of the scribal role. ${ }^{20}$

\section{The Three Woes against the Scribal Scholars}

Luke 11:45-53, as has been noted, is unique in terms of how Luke presents the scribes. Elsewhere, they are, in the majority of cases, lumped in with another group (Pharisees or chief priests) as opponents of Jesus, or, in a few places, they are referred to alone. But here the scribal scholars are concurrently associated with, yet distinguished from, the Pharisees. In Luke's framing of this narrative, he presents six woes, the first three against the Pharisees (11:42-44) and the second three against the scribal scholars $(11: 45-53) .{ }^{21}$

Jesus' denunciation of the Pharisees is not over their Torah interpretation, but rather the hypocrisy and arrogance in their halakah, that is, how they are actually living (Sanders, 103). However, the scribal scholars are also insulted by Jesus' censure (11:45), perhaps because the Pharisaic halakah in question is at least partially built on their scripture interpretations. The scribal scholar's remark in 11:45 is intriguing because it associates the two groups while at the same time clarifying that the scribal scholars understood themselves as distinct.

The nature of the three woes against the scribal scholars is clearly different from that of those leveled against the Pharisees. Jesus criticized the Pharisees for their actions of hypocrisy (11:42) and conceit (11:43), and the indirect negative influence of their conduct on the people (11:44). The scribal scholars, on the other hand, are rebuked specifically for their failed leadership of the people, par-

20 It is also just possible, though the lack of evidence precludes making the argument, that vouixós

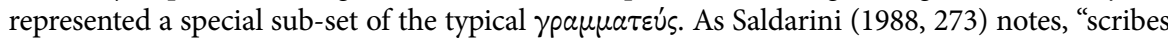
may have at times had organizations for which we have no evidence." In that case, the term $\nu$ outxos, based on its use in Luke, could have been a term for a higher-level category of scribalism.

21 There are actually seven criticisms overall, but the first criticism to the Pharisees (vs. 39-41) is not introduced with a woe. In this way, Luke frames the larger passage symmetrically with three woes to each group. Parallels are found throughout Matthew $23(4,13,29-36)$, but the arrangement and some wording is different with each evangelist. Notably in Matthew, Jesus addresses the scribes and Pharisees together in each woe. Bock (2:1107) argues that the parallels with Matthew are "conceptual not verbal" such that this pericope reflects an independent tradition from that on which Matthew 23 is based. Although Bock's view is a minority one, he does succeed in at least putting into question the assumption that these narratives are based on the same source or tradition. Jesus may indeed have given similar rebukes in different settings. However, such a view does not preclude a distinctive narrative structuring and vocabulary usage by Luke. 
ticularly in regard to their teaching. In the first case (11:46), they burden the people with burdens hard to carry but do not touch these burdens themselves. These burdens most likely reflect their interpretation and application of the Mosaic law (Fitzmeyer, 1985, 945), the elaboration of which made obeying it a burden too heavy to bear, even for themselves (Green, 1997, 474). ${ }^{22}$

Secondly (11:47-51), Jesus associates their building of the prophets' tombs with their ancestors' killing of the prophets. ${ }^{23}$ The implication is that the scribal scholars continue in the tradition of their ancestors in actively silencing the revealed word of the prophets. This woe is given the most attention by Jesus and is most crucial for the present argument, and so will be addressed in more detail in the following two sections. Finally, the scribal scholars are reprimanded for their rejection of true knowledge (11:52), and the resultant prevention of others from gaining it. In each case then, the scribal scholars are rebuked for their failures in properly teaching the people: they overburden them in Torah instruction, they silence the prophetic word, and prohibit knowledge.

Fitzmeyer links these three woes against the scribal scholars with the three sections of the traditional Hebrew canon: law, prophets and wisdom $(1985,945)$. There are great differences of opinion about the extent, arrangement, and open or closed nature of a canon of Jewish scriptures at the time of Jesus (McDonald and Sanders, 2002, 4). Some have argued for a fixed, tripartite canon already in the first century, partially based on material from our passage (Beckwith, 1984), while others insist there were no such canonical limitations at that point in history (Sundberg, 1964). ${ }^{24}$

However, a more nuanced approach has been offered by Steven Chapman (2000) and Christopher Seitz (2009), who understand a functioning tripartite "grammar" or framework at work in the New Testament era (see also Dempster, 1997), even if it was still not "officially" closed. This is consistent with evidence within the New Testament in numerous places where the phrase "law and prophets" clearly refers to a functioning group of scriptures. ${ }^{25}$ The entire three part division appears to be known by Luke (24:14) who cites Jesus' reference to "the law of Moses, the prophets and the Psalms." Earlier evidence from the prologue

22 While the particular Greek word is different (ßápoc instead of poptiov in Luke 11:46), Luke’s summary of the Jerusalem council's decision regarding Gentile Christians and the law in Acts 15:28 also articulates the concept of law requirements in terms of a burden.

23 Some commentators (Marshall, 1978, 500) note that because the audience of this woe is not specified, it is addressed to an audience wider than the scribal scholars. This is doubtful, though, because of the clear symmetry of the passage overall (Nolland, 1993, 667).

24 It is uncertain that the main rabbinic evidence for the traditional order of the Hebrew canon (b. B. Bat. 14b) can be retrojected back into the first century A. D. 
to Ben Sira refers to the "law, prophets and other books." ${ }^{26}$ This evidence at the very least points to the existence of the kind of tripartite framework described by Chapman and Seitz in Jesus' and Luke's time, and that Luke himself was aware of it.

Further, the OT itself provides references that point to a tripartite revelatory tradition, even if not yet to a tripartite canon of written scriptures. Jeremiah (18:18) and Ezekiel (7:26) both refer to revelatory traditions and persons associated with those traditions (Dempster, 2008). In both Jeremiah and Ezekiel, the Torah, or instruction, is associated with the role of the priest (see also above on Eleazar in 4 Maccabees). Interestingly, in Hayward's interpretation of the Targumic evidence of these passages and others in the prophetic corpus, he concludes that "the Targum of the Latter Prophets therefore understands scribes as Torah-scholars. They are linked with the priests in their handling of the Law and are, like them, included in the prophets' criticisms and polemic when appropriate" (Hayward, 1985, 217). This is consistent with the evidence in Luke which describes the scribes as Torah interpreters and links them with the priests in Jerusalem.

Jeremiah also associates the "word" with the prophet, and counsel with the wise man. Similarly, Ezekiel relates "vision" with the prophet, and counsel with the elder. These two OT passages strengthen the likelihood that there already existed a three-stream revelatory tradition around the time of the conquest and exile. As written scriptures which were associated with these revelatory traditions were collected and used in worship, they likely would have been thought of and perhaps organized in these categories, eventually taking the tripartite shape of the later Hebrew Bible. For the present work, it is not necessary to argue for a fixed canon in Jesus' day, but it does appear likely that at the very least a tripartite revelatory or canonical framework did in fact exist and can be viewed as a background to the three woes against the scribal scholars ( $\nu \mu$ ixoí).

Not only has Luke used voulxós in this pericope to identify the scribal scholars as official scripture interpreters and rhetorically intensify a broad scriptural allusion, but the correspondence of the three-part structure of the passage to a three-stream revelatory tradition and tripartite canonical framework further bolsters this allusion. The passage thus resounds with echoes of the whole of Jewish scripture. I now examine how Luke fits Jesus and his emissaries within such a revelatory tradition and canonical framework.

26 As is evident in these sources, the third section, commonly referred to as the "writings" in rabbinic tradition, is less precise than "law and prophets," though wisdom is certainly a key element in this section. The point has been made that the "other books" in Ben Sira could easily refer to a growing, non limited number of sacred writings. But even if so, the "law" and "prophets" are clearly delimited, and the "other books" represent a third stream that is associated in Ben Sira with "instruction and wisdom." 


\section{The Revelation of the "Wisdom of God"}

In the second woe against the scribal scholars, Jesus rebukes them for "building the tombs of the prophets" whom their fathers had killed. Jesus' point here seems to be that in building the tombs, the current scribal scholars-as Torah and scripture interpreters-are confirming the work of their fathers. By entombing the prophets, the prophets are symbolically historicized and silenced by the scribal scholars. As Marshall argues, Jesus thus accused the current generation of leaders of imitating their fathers by refusing to listen to the word of the prophets (Marshall, 1978, 501).

This assertion infers Jesus' next statement that "the Wisdom of God has said 'I will send to them prophets and apostles."' Interpreters have offered a number of proposals regarding the referent of "Wisdom of God." It has been suggested that it is referring to a now lost apocryphal book by the name "Wisdom of God," but there is no evidence of such a work (Marshall, 1978, 502-3). Others have proposed an early church prophecy, understood to have come from the resurrected Jesus and consequently read back onto the lips of the pre-resurrection Jesus in the underlying tradition (Ellis, 1963). But this too is highly speculative, and assumes Luke's account and its underlying tradition to have no historical basis. Moreover, there is no strong evidence that such post-resurrection prophecies in the church were used in such a way.

Marshall concludes that it was perhaps a Jewish tradition re-used by Jesus and then subsequently taken up by the early church and re-worded again (1978, 502-3). In each of these suggestions, there is little evidence to go on and a seeming reluctance to attribute the ipsissima vox of this passage to Jesus. Matthew's parallel reports that Jesus spoke these words in the first person, explicitly making Jesus speak as God's wisdom. However, Matthew's more developed wisdom Christology may point to his redaction of the original source (Suggs, 1970, 59-60), though, as I shall argue below, Luke's and Matthew's renditions are not as different as they might seem at first.

Dale Allison $(2000,149-52)$ suggests a background to the underlying Q tradition (Luke 11:49-51; Matt 23:34-36) in 2 Chron 24:19-27. In particular, Allison finds the vocabulary of 2 Chron 24:19 very close to the sending passages in Luke and Matthew, though close similarities can also be seen in 2 Chron 36:15-16.

\begin{tabular}{|c|c|c|c|}
\hline $\begin{array}{c}\text { LXX 2 } \\
\text { Chronicles 24:19 }\end{array}$ & $\begin{array}{c}\text { LXX 2 } \\
\text { Chronicles 36:15-16 }\end{array}$ & Matthew 23:34 & Luke 11:49 \\
\hline 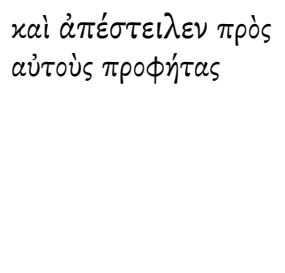 & 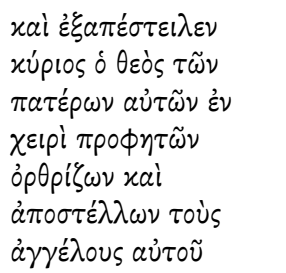 & 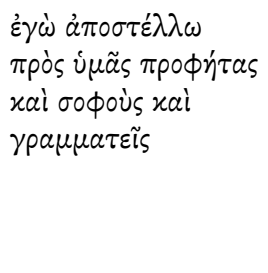 & 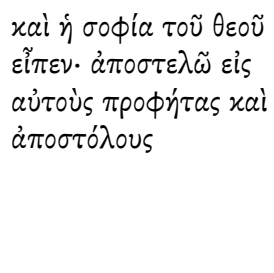 \\
\hline
\end{tabular}


A comparison of these texts, however, reveals a key difference in the verb tenses of $\dot{\alpha} \pi \circ \sigma \tau \dot{\varepsilon} \lambda \lambda \omega$. The Chronicler's use of the past tense shows he is looking back at an historical pattern of apostasy, divine sending of prophets, the rejection of those prophets and divine judgment. ${ }^{27}$ However, in Matthew the tense of the verb is present, making explicit, in conjunction with the attribution of the words in the first person to Jesus, that Jesus is sending revelatory agents in the present of the narrative world, and thus recapitulating this pattern. ${ }^{28}$ In the Lukan passage, Jesus refers in the past tense to the speech of the Wisdom of God ( $\varepsilon i \pi \varepsilon v)$, but within that speech, $\dot{\alpha} \pi \circ \sigma \tau \dot{\varepsilon} \lambda \lambda \omega$ is in the future tense $(\dot{\alpha} \pi \circ \sigma \tau \varepsilon \lambda \tilde{\omega})$.

In both Matthew's and Luke's account then, the sending-apostasy-judgment pattern in the canonical past is now updated to include the present and future. This climactic canonical recapitulation is confirmed by Jesus' charge that the present generation would be liable for the blood of all the prophets (Luke 11:50; Matt 23:35). In this way, "the historic language of Chronicles" is moved "to the eschatological time of Jesus" (Allison, 2000, 149).

Allison also proposes that, based on Baruch 3:36-4:1, Wisdom is identified with the Torah, and since the Torah also often represents all of written scripture, "Wisdom of God' is a way of referring to the Bible" as a whole $(2000,152)$. Even if this second part of his proposal is less persuasive-requiring as it does an assumption that the underlying tradition or Luke has made the same connections found in Baruch ${ }^{29}$-Allison's understanding of this passage as an eschatological recapitulation of biblical history, now continued in the ministry of Jesus and his emissaries, is convincing. However, the updating of the Chronicles pattern as shown above suggests that the speech of the "Wisdom of God," while based in the past and linked with scripture in Chronicles, is now realized in a climactic sense in the present and near future of the narrative world of Luke-Acts.

Throughout Luke's two-volume work, prophetic sending $(\dot{\alpha} \pi \circ \sigma \tau \dot{\varepsilon} \lambda \lambda \omega)$ is a prominent theme. After the divine sending of angels early in the gospel (1:19, $26)$, John (7:27) is sent as God's prophetic messenger to prepare the way for Jesus, and Jesus is shown to be sent by God to fulfill Israel's eschatological promises (Luke 4:18, 43; Acts 7:37) and to prophetically call Israel to repentance (Acts 3:26), only to be rejected and executed (Acts 7:52). But Jesus also functions as a sender himself with divine authority, both in his earthly ministry (Luke 9:1-6;

27 This same pattern is present on a larger scale in the entire Deuteronomistic history.

28 Matthew's prophets, wise ones and scribes may also correspond to a tripartite revelatory framework.

29 It might be argued that "Wisdom of God," in light of the Chronicles background above, could simply be a way of referring to the Chronicles texts by way of a reference to the somewhat ambiguous third section of the revelatory framework. 
10:1-20; 22:35), and in his risen state (Acts 1:8 9:17; 26:17). ${ }^{30}$ Indeed, prophets and apostles are elsewhere affirmed as the two chief offices of leadership in the early Christian movement (Acts 1:2; 11:27; 13:1; 15:32; 1 Cor 12:28-29; Eph 2:20; 3:5; 4:11; Rev 18:20).

Jesus, whom Luke describes as full of divine wisdom on multiple occasions (Luke $2: 40,52 ; 11: 31$ ) prior to the present passage, thus presents Jesus as both one of the sent ones, but also the agent through whom divine sending would now occur. In that sense, Jesus' reference to the Wisdom of God in 11:49 not only reflects the revelatory speech of scripture past applied to the present, but, in a climactic recapitulation, implies that Jesus now actualizes in himself the revelatory speech of the Wisdom of God for the present of Luke's narrative, with a view to the present and future ministry of the apostles in both the gospel and in Acts. The phrase "Wisdom of God" therefore functions in Luke as a reference to past scripture now typologically actualized in the revelatory authority of Jesus' own person, and in this way Matthew's and Luke's renditions are not as conceptually different as they might otherwise seem. This parallel role as sent one and sender also conforms to a derivative yet parallel relationship between the ministry of Jesus in the Gospel of Luke and the ministry of the apostles sent by him in Acts. ${ }^{31}$

\section{The Identity of Zechariah and the "Canonical" Span of Martyrs}

The climactic recapitulation identified above in the divine sending of Jesus, and Jesus' own sending of prophets and apostles, corresponds with a climactic recapitulation of divine judgment on the current generation of leaders who have rejected Jesus and failed in their roles as Torah interpreters and teachers. Jesus declares that the blood of all prophets would be charged against the present generation. He further sets parameters for these prophets as ranging from Abel to Zechariah.

Even though Abel was not a prophet, his death at the hands of Cain is understood in 4 Macc 18:10-11 as the first canonical martyrdom (cf. 1 En. 22:7). ${ }^{32}$ The identity of this Zechariah, however, both here and in Matthew 23:35, has been somewhat more problematic for interpreters. Part of the problem is brought

30 Related to this, the risen Jesus promises to send ( $\dot{\varepsilon} \gamma \omega \dot{\alpha} \pi \circ \sigma \tau \varepsilon \lambda \lambda \omega)$ the promised Spirit to empower the apostles for mission in Luke 24:49.

31 The parallelism between Luke and Acts has been shown by many interpreters. See, for example, Denova (1997).

32 Interestingly, this account of canonical martyrdoms is immediately preceded by a reference to the teaching of the law and the prophets (18:10). 
about by Matthew's identification of Zechariah as the son of Barachiah. But the son of Barachiah, the prophet associated with the book of Zechariah (1:1) is not known to have been martyred and there is no known tradition of his martyrdom (Davies and Allison, 1997, 318). Even though Luke omits the patronymic, the identity of Zechariah is no clearer in the third gospel. Three other options have been offered. Some church fathers suggest that the Zechariah in question is the priest and father of John the Baptist. But there is no other evidence that he was martyred, and it is difficult to see why he would be named as the climax of a list of martyrs when his martyred son (Luke 9:7-9) was already named by Jesus as the greatest prophet.

The two possibilities held by modern scholars are Zechariah, son of Jehoiada in 2 Chron 24:20 and Zechariah, son of Bareis, whose martyrdom in 69 A.D. by zealots near the temple is recorded by Josephus. ${ }^{33}$ This latter identification is quite problematic on a number of grounds (Chapman, 1912), foremost because this Zechariah was neither a prophet, nor a Christian, nor was he killed by the official leadership, but by zealots. ${ }^{34}$ Moreover, the location of the killing requires that the Zechariah in question must have been a priest (Davies and Allison, 1997, 318).

Most interpreters therefore rightly hold to the identity of Zechariah as the son of Jehoiada in 2 Chron 24:15-22. This Zechariah was a priest, but also functioned in a prophetic role, calling Judah's king and princes to repentance, and was slain in the temple as a result. Further, I have already shown above that 2 Chronicles 24 provides a suitable background for the "Wisdom of God" sending passage. The identification of the Zechariah in Luke 11:51 with that of the son of Jehoiada in 2 Chron 24:20 further confirms and strengthens this intertextual link.

The meaning of the span of martyrs from Abel to Zechariah is a much more divisive issue. Many interpreters conclude that the span does not reflect a chronological history, but a canonical one since Rabbinic tradition places Chronicles at the end of the third section (the Writings) of the tripartite Hebrew canon. ${ }^{35}$ Thus, the span from Abel to Zechariah corresponds to the range of canonical books in the Hebrew canon from Genesis to Chronicles. Beckwith $(1986,211-22)$ utilizes this passage and Matt 23:35 therefore to argue for such a fixed Hebrew canon in the first century, which is equivalent to the canonical arrangement attested to in the Talmud (b. B. Bat 14b-15a).

While many interpreters follow this line without much consideration, the ca-

33 The Jewish War, IV.334-344.

34 As Chapman $(1912,402)$ notes, "if he was really a Christian martyr, he would be more famous."

35 Chronologically, there is a later scriptural martyrdom reported in Jer 26:20-23. 
nonical range interpretation has been disputed. ${ }^{36} \mathrm{H}$. G. L. Peels (2001) concedes the likelihood that the identity of this Zechariah is that of the son of Jehoiada, but challenges Beckwith's and others' assertions that this span represents a "canonical" range. He argues that a "canonical" span of martyrs does not fit in the immediate context because only those martyrs would then be avenged on "this generation." Rather, Peels argues, the span should be explained "primarily in a qualifying sense," that is, inclusive of martyrs whose blood cries out for vengeance. According to Peels, the killing of Abel and of Zechariah are the only two instances that fit the required criteria-a violent killing of an innocent person linked to that person's dedication to God, and a cry for vengeance (Peels, 2001, 598). He concludes that "the text is referring to two figures who over a span of centuries portray the entire tragedy of the murder of God's servants" (Peels, 2001, 599). Further, he states that

Jesus' intention is not so much to mark the starting point and end point of a linear canonical time span so as to touch upon two deeply incisive moments of an occurrence which has been going on for centuries and still continues in the present (Peels, 2001, 599).

Thus, according to Peels, neither Matt 23:35 nor Luke 11:50 represent a canonical order. While Peels does provide a compelling counter to the idea of a canonical span conceptually, his account fails to account for the clear syntactical construction of àmo ... $\varepsilon^{\prime} \omega \varsigma$, which points to the "blood" spilled within these two parameters. In fact, Peels concedes this "temporal aspect" early on in his argument only adding that the phrase is "intended to say more than that" (Peels, 2001, 597).

Peels' earlier complaint that the avenged martyrs would be limited to canonical martyrs actually misses the larger point of the passage that Jesus and his sent prophets and apostles represent a climactic recapitulation of scriptural history. The claim that all the blood will be required of "this generation" cannot literally mean that the generation of Jesus' day is solely responsible for the actions of all previous generations, for clearly divine judgment had already been rendered in the past, as 2 Chron 36:19-20 clearly attests.

Rather, the text expresses a climactic typology of judgment. Just as Jesus and his sent ones typologically fulfill the role of the prototypical canonical prophets who were persecuted and killed within scriptural history, the current generation of scribal scholars who will persecute Jesus and his emissaries typologically fulfill the role of the prototypical persecutors. But because these events now take place

36 For a criticism of Beckwith, see R. L. Harris (1990, 75-84), who takes issue with Beckwith's position that Chronicles was at the end of the canon, and with the idea of a tripartite canon in general. He does not find the identification of Zechariah as that of Zechariah of Jehoiada convincing, but provides no compelling alternative. 
at the eschatological advent of Messiah, they are a climactic recapitulation of the earlier canonical events. Thus, the statement "from Abel to Zechariah" is best understood as setting canonical parameters for scriptural prototypes of martyrs, to which Jesus and his emissaries bring to eschatological, typological fulfillment.

However, Peels' concern about Beckwith's use of the passage to prove a closed OT canon remains an appropriate caution. The "canonical" range of prototypical martyrs cannot prove without question that such a canonical arrangement was accepted in all streams of thought in Judaism at the time, nor that the collection was necessarily closed in some official manner. That there may have been competing orders or arrangements is possible and perhaps likely. ${ }^{37}$ This does not, however, preclude the possibility that there was a Genesis - Chronicles canonical tradition functioning in early Jewish and Christian circles. ${ }^{38}$ Indeed, as was argued above, there is enough evidence in the OT itself and in second temple Judaism to suggest a tripartite canonical framework was in place. The three-fold woes to the vонıкоi, and the canonical span of martyrs in Luke 11:49-51 contribute to the evidence of the presence of such a canonical framework.

\section{Conclusions and Implications}

I have shown above that four elements in Luke 11:45-51 contribute to incorporate Jesus and his emissaries within a tripartite canonical framework. Luke's

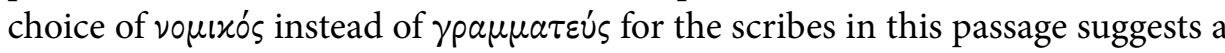
rhetorical tactic to emphasize the role of scripture interpretation for the scribal scholars, and provide a broad allusion to scripture. In addition, the structuring of three woes against these vоцाкоi, which correspond thematically to a tripartite canonical framework, bolsters this broad allusion to scripture as a whole.

Third, in the central woe, the revelatory speech of the "Wisdom of God" is shown to be based on a sending-apostasy-judgment pattern from 2 Chronicles 24 and 36 , but now updated and recapitulated in the authoritative person of Jesus, who himself sends apostles and prophets. This recapitulation serves to incorporate Jesus and his emissaries within the alluded to tripartite framework. Finally, the canonical span of martyrs from Abel to Zechariah confirms this typological recapitulation such that the expected future martyrdoms and persecutions of both Jesus and the apostles in the early Christian movement, and the judgment

37 Some Hebrew manuscripts place Chronicles at the head of the third section (Braun, 1986, xix).

38 Alternatively, Chronicles could have been understood as a representative book of the third section and still served the same purpose. 
on the present generation of scribal scholars and their allies, are typologically linked with the earlier persecution of the scriptural prophets by the leaders of Judah in 2 Chronicles 24 and 36.

Luke's peculiar presentation of this episode thus serves to present the persecution and killing of Jesus and his emissaries as the climactic continuation of the canonical past. In so doing, this text points to Luke's writings overall, both his gospel and the subsequent volume of Acts, to be written continuations of a tripartite revelatory tradition and canonical framework of OT scriptures.

\section{Bibliography}

Allison, Dale C. 2000. The Intertextual Jesus: Scripture in Q. Harrisburg, PA: Trinity Press International.

Balla, Peter. 2002. "Evidence for an Early Christian Canon (Second and Third Century)." In The Canon Debate, edited by Lee Martin McDonald and James A. Sanders, 372-85. Peabody, MA: Hendrickson.

Beckwith, Roger. 1986. The Old Testament Canon of the New Testament Church and Its Background in Early Judaism. Grand Rapids: Eerdmans.

Bickerman, Elias J. 1945. “The Date of Fourth Maccabees.” In Louis Ginzberg Jubilee Volume on the Occasion of His Seventieth Birthday. New York: The American Academy for Jewish Research.

Bock, Darrell L. 1996. Luke Volume 2: 9.51-24.53. Vol. 2.2 vols. Baker Exegetical Commentary on the New Testament 3B. Grand Rapids: Baker.

Braun, Roddy. 1986. 1 Chronicles. Word Biblical Commentary 14. Waco, TX: Word.

Chapman, John. 1912. "Zacharias, Slain between the Temple and the Altar." The Journal of Theological Studies os-XIII (51): 398-410.

Chapman, Stephen B. 2000. The Law and the Prophets: A Study in Old Testament Canon Formation. Forschungen zum Alten Testament 27. Tübingen: Mohr Siebeck.

Davies, W. D., and D. C. Allison. 1988-1997. A Critical and Exegetical Commentary on the Gospel According to Saint Matthew. 3 vols. ICC. Edinburgh: T\&T Clark.

Dempster, Stephen G. 1997a. "An 'Extraordinary Fact': Torah and Temple and the Contours of the Hebrew Canon, Part 1." Tyndale Bulletin 48 (1): 23-56.

- - . 1997b. "An 'Extraordinary Fact': Torah and Temple and the Contours of the Hebrew Canon: Part 2." Tyndale Bulletin 48 (2): 191-218. 
Dempster, Stephen G. 2008. “Torah, Torah, Torah.” In Exploring the Origins of the Bible: Canon Formation in Historical, Literary, and Theological Perspective, edited by Craig A. Evans and Emanuel Tov, 87-127. Acadia Studies in Bible and Theology. Grand Rapids: Baker Academic.

Denova, Rebecca I. 1997. The Things Accomplished Among Us: Prophetic Tradition in the Structural Pattern in Luke-Acts. Library of New Testament Studies 141. Sheffield, UK: Sheffield Academic Press.

deSilva, David A. 1998. 4 Maccabees. Guides to Apocrypha and Pseudepigrapha. Sheffield England: Sheffield Academic Press.

deSilva, David A. 2006. 4 Maccabees: Introduction and Commentary on the Greek Text in Codex Sinaiticus. Septuagint Commentary Series. Leiden: Brill.

Ellis, E. Earle. 1963. "Luke 11:49-51: An Oracle of a Christian Prophet?" Expository Times 74 (5): 157-58.

Fitzmyer, Joseph A. 1985. The Gospel According to Luke X-XXIV: Introduction, Translation, and Notes. Vol. 2. 2 vols. AB 28a. Garden City N.Y.: Doubleday.

Gowler, David B. 1994. "Hospitality and Characterization in Luke 11:37-54: A Socio-Narratological Approach." Semeia 64: 213-51.

Green, Joel B. 1997. The Gospel of Luke. New International Commentary on the New Testament. Grand Rapids: Eerdmans.

Harris, R. Laird. 1990. "Chronicles and the Canon in New Testament Times." Journal of the Evangelical Theological Society 33 (1): 75-84.

Hayward, Robert. 1985. "Some Notes on Scribes and Priests in the Targum of the Prophets." Journal of Jewish Studies 36: 210-21.

Kruger, Michael J. 2012. Canon Revisited: Establishing the Origins and Authority of the New Testament Books. Wheaton, IL: Crossway.

-_- 2013. The Question of Canon: Challenging the Status Quo in the New Testament Debate. Downer's Grove, IL: IVP Academic.

Marshall, I. Howard. 1978. The Gospel of Luke: A Commentary on the Greek Text. New International Greek Testament Commentary. Grand Rapids: Eerdmans.

McDonald, Lee Martin, and James A. Sanders. 2002. "Introduction." In The Canon Debate, edited by Lee Martin McDonald and James A. Sanders, 3-17. Peabody, MA: Hendrickson.

Nolland, John. 1993. Luke 9:21-18:34. WBC 35b. Dallas: Word Books.

Peels, H. G. L. 2001. “The Blood 'from Abel to Zechariah' (Matthew 23,35; Luke 
11,50f.) and the Canon of the Old Testament." Zeitschrift für die alttestamentliche Wissenschaft 113 (4): 583-601.

Redditt, Paul L. 1983. "The Concept of Nomos in Fourth Maccabees." Catholic Biblical Quarterly 45: 249-70.

Saldarini, Anthony J. 1988. Pharisees, Scribes and Sadducees in Palestinian Society: A Sociological Approach. Wilmington, DE: Michael Glazier.

Sanders, Jack. 1987. The Jews in Luke-Acts. Philadelphia: Fortress.

Schams, Christine. 1998. Jewish Scribes in the Second-Temple Period. Journal for the Study of the Old Testament: Supplemental Series 291. Sheffield: Sheffield Academic Press.

Seitz, Christopher R. 2009. The Goodly Fellowship of the Prophets: The Achievement of Association in Canon Formation. Acadia Studies in Bible and Theology. Grand Rapids: Baker Academic.

Smith, Dennis. 1987. "Table Fellowship as a Literary Motif in the Gospel of Luke." Journal of Biblical Literature 106 (4): 613-38.

Smith, D. Moody. 2000. "When Did the Gospels Become Scripture?" Journal of Biblical Literature 119: 3-20.

Steele, E. Springs. 1984. "Luke 11:37-54: A Modified Hellenistic Symposium?” Journal of Biblical Literature 103 (3): 379-94.

Suggs, M. Jack. 1970. Wisdom, Christology, and Law in Matthew's Gospel. Cambridge: Harvard University Press.

Sundberg, Albert. 1964. The Old Testament of the Early Church. Cambridge: Harvard University Press.

Thellman, Gregory S. 2013. "Scribes." Edited by Joel B. Green, Jeannine K. Brown, and Nicholas Perrin. Dictionary of Jesus and the Gospels. Downer's Grove, IL: IVP Academic.

-_- 2016. "Revealing the Past and Envisioning the Future: Matthew's Apocalyptic Frame." Ph.D. diss., Wheaton, IL: Wheaton College. 
Gregory S. Thellman

\title{
Inkorporiranje Isusa i njegovih poslanika u tripartitni kanonski okvir (Lk 11,45-53)
}

\begin{abstract}
Sažetak
Ova složena kritička egzegetska studija razmatra osobit način na koji Luka u svome evanđelju 11,45-51 koristi Isusove zazive "Jao vama!" protiv pisara-učenjaka. Prepoznaju se četiri elementa Lukine prezentacije, koji doprinose inkorporiranju Isusa i njegovih poslanika u izričito tripartitni kanonski okvir. Dokazuje se da Lukina neobična upotreba grčkog izraza vouıxós predstavlja retoričku oznaku kojom se naglašava uloga pisara-učenjaka kao tumača Svetoga pisma i kojom se aludira na Sveto pismo u cijelosti. Povezanost između tri zaziva protiv vouıxol s tripartitnim hebrejskim kanonom nameće se kao daljnji dokaz aluzije na Sveto pismo i tradiciju trostruke objave. Potom se raspravlja o dvama elementima unutar drugog zaziva, objavi "mudrosti Božje" te rasponu mučenika iz prošlosti, pri čemu se ustanovilo da postoje intertekstualne poveznice sa 2. Ljetopisa 24 i 36, što navodi na činjenicu da odabrani ulomak predstavlja tipološku rekapitulaciju prošlih progona i mučeništava, no također i njihovu osudu. U članku se zaključuje da ti posebni elementi pokazuju da Luka tipološki inkorporira Isusa i njegove poslanike unutar tripartitne tradicije objave i kanonskog okvira te da svojim daljnjim implikacijama, Lukino pisano svjedočanstvo (Luka - Djela) progona i ubijanja Isusa i njegovih poslanika potvrđuje samostalno predstavljanje toga pisanog svjedočanstva, kao vrhunca u nastavku starozavjetnih tekstova.
\end{abstract}

